\title{
Consumer behaviour factors and contemporary trends on the luxury goods market
}

\section{Čimbenici ponašanja potrošača i suvremeni trendovi na tržištu luksuzne robe}

\begin{abstract}
Regardless of the economic crisis all over the world, the market of luxury goods thrives continuously. The research aims to provide an extensive overview of the theoretical background of this occurrence and contemporary trends, analyse the consumer behaviour factors in buying luxury goods and the effect of online shopping as a form of digitalisation on the sales of luxury goods, with particular emphasis upon the sale of luxury handbags. The methods were consisted of an overview of relevant scientific and expert literature, reports of market experts for the luxury goods markets and official statistic databases. Research resulted in detecting digitalisation as the biggest change and trend of luxury industry. Online sales and revenues of luxury goods' continuous growth indicates that digitalisation and its tools such as online shopping are an important consumer behaviour factor, affecting the sales of luxury goods, including luxury handbags, to a significant extent.
\end{abstract}

Keywords: luxury goods, consumer behaviour factors, digitalisation, online shopping, social media

JEL classification: D11, D91, E21, L67, M31, M37

\section{Sažetak}

Unatoč gospodarskim krizama, tržište luksuzne robe kontinuirano prosperira. Cilj istraživanja je pružiti opsežan teorijski pregled ove pojave te pregled suvremenih trendova, analizirati čimbenike koji utječu na ponašanje potrošača luksuzne robe i utjecaj internet prodaje kao aspekta digitalizacije na prodaju luksuzne robe, s posebnim naglaskom na prodaju luksuznih torbica. Metode istraživanja obuhvaćale su pregled relevantne znanstvene i stručne literature, izvješća stručnjaka za tržište luksuzne robe i službenih statističkih baza podataka. Istraživanje je utvrdilo da je digitalizacija najveća promjena i najveći trend luksuzne industrije. Kontinuiran porast internet prodaje i prihoda luksuzne robe pokazuje da su digitalizacija i digitalni alati poput internet prodaje važni čimbenici kupovine potrošača, značajno utječući na prodaju luksuzne robe, uključivo i prodaju luksuznih torbica.

Ključne riječi: luksuzna roba, čimbenici ponašanja potrošača, digitalizacija, internet prodaja, društveni mediji

JEL klasifikacija: D11,D91,E21, L67, M31, M37 
Pajić, M.A.

Consumer behaviour factors and contemporary trends on the luxury goods market

\section{Introduction}

Luxury goods represent a specific phenomenon in today's society and economy. Firstly, regardless of the political and economic crisis all over the world, the industry of luxury goods grew fast and still continues to thrive (Bain and Company, 2017; CB Insights, 2018), against all odds and unlike other industries. Secondly, perceived value of luxury goods is different from different status and wealth levels (Kasztalska, 2017), which is why the definition of luxury goods is rather relative and therefore difficult to unanimously define. While wealth and luxury used to be reserved only for the privileged few due to their accomplishments, education or heritage, today they are more accessible to everybody due to globalisation and digitalisation. The understanding of this social and economic phenomenon and unparalleled success of luxury industry lays firstly in identifying psychological aspects of consumer behaviour in buying luxury goods, what drives and motivates consumers to purchase luxury goods, as well as what influences their decision-making process of buying luxury goods.

The motivation for exploring this topic and this specific problem arose from examining new trends in the luxury goods markets, which might even threaten traditional corporate strategies. An overview of relevant scientific and expert literature and other sources was conducted, and it was found that scholastic literature mainly focuses on assessing the psychological aspects of consumer's desires for luxury goods for displays of wealth, status and prestige (Han et al., 2010; Hennigs et al., 2015; Hennigs et al., 2016). Many different characteristics of luxury goods have been assessed (Kasztalska, 2017; Tekin et al., 2016; Fuerst and Shimizu, 2016; Hennigs et al., 2015; Hennigs et al., 2016), as well as luxury purchasing motivations (Han et al., 2010; Caserta, 2008; Yang and Mattila, 2017) and influencing factors on consumer buying behaviour of luxury goods (Nwankwo et al., 2014; Ramya and Mohamed, 2016; Singh et al., 2014; Tekin et al., 2016; Thangasamy and Patikar, 2014), all of which play a major part in affecting and forming consumer behaviour in buying luxury goods. However, contemporary literature on online shopping as one of the consumer behaviour factors of luxury goods has been rather scarce, leaving a gap in this specific field.
Hence, the research problem is to detect whether online shopping is in fact one of the consumer behaviour factors, and subsequently, in the luxury market and industry's continuous growth. The research question is to what extent has online shopping affected the sales of luxury goods, with particular emphasis on the sale of luxury handbags. This research aims to provide an extensive overview of the topic by bringing together contemporary trends and economic theory in order to find and understand the reasoning behind today's occurrences on the luxury goods market. Furthermore, the aim is to analyse the most significant factors that influence consumer behaviour on the luxury goods market and their impact in today's changed environment of luxury goods markets, as well as to establish whether online shopping behaviour, as an aspect of digitalisation, is one of the consumer behaviour factors on the luxury industry market.

This research looks in detail into all aspects of luxury goods, accompanying trends and consumer behaviour. The review includes a comprehensive analysis of relevant scientific and expert literature and examines other sources that are recent, relevant and of high quality, and that appropriately reflect the state-of-the-art, in order to provide a wide, yet detailed approach from both scientific and expert aspects to make sure of the academic and practical relevance.

This research is consisted of five main chapters and is structured as follows. After introduction, the theory, practical aspects, definition and characteristics of luxury goods, as well as luxury-purchasing motivations and characteristics of consumer behaviour are presented in chapter two. Chapter three discusses the analysis of the luxury industry trends, with provided findings of luxury spending trends and the role of social media and digital impact. Chapter four gives insight into consumer behaviour in buying luxury goods and the role of digitalisation. Lastly, conclusion is laid out in chapter five.

\section{Luxury goods}

Luxury goods are not a new concept or only recently in fashion. They have been an acknowledged concept since the beginning of ages. For example, according to Han et al. (2010:15) research, laws throughout history used to provide specific rules 
for what kind of clothes and accessories every social class was allowed to have and carry, as well as in what price ranges they could manoeuvre. Although formal distinctions do not exist anymore, purchasing, using and displaying luxury goods as symbols of wealth, status and class never seized to exist. However, what was once available only to a privilege few, today is accessible to a continuously growing number of people. Wealth and luxury used to be reserved for the privileged few due to their accomplishments, education or heritage, but wealth and luxury today are more accessible to everybody due to globalization, internet and new professions.

When it comes to defining luxury goods, Piiroinen (2014) explains that "[t]he word "luxury" originally comes from the Latin expression "luxus" indicating "extravagant living, magnificence, indulgence and majesty"” (Shukla, n.d., cited in Piiroinen, 2014:26). Luxury goods are products and services that are not essential for living, but rather goods that are considered to be a status indicator, and therefore, are highly desired. According to Han et al. (2010), luxury goods' primary role is to provide prestige to its owners (Grossman and Shapiro, 1988, cited in Han et al., 2010:16). Shoes, coats, hats and bags, as well as other items of clothing or any other purpose, are considered essential and necessary in most parts of the world. However, there are items that are necessary purely for their purpose, and there are certain items and brands that distinguish their owners due to their features, and are therefore considered luxury goods. Everyone has their own preferences of goods that are most important for them, and when the situation asks for narrowing choices to only one, people will always choose a luxury good of their preference. Although luxury goods are not considered a necessity, the characteristic that differs luxury handbags from other luxury goods is that luxury handbags are more often considered an everyday necessity.

Although they do not fulfil essential needs in everyday life, luxury goods are considered to be a magnifying factor for quality and comfort of life. Luxury goods are, among other things, highly expensive, so "[t]he ability to purchase or finance a luxury item is directly proportionate to one's income or assets" (Investopedia, 2018, "Luxury Item": para. 1), as well as professional and social status. In that sense, the perception of goods being luxury and valuable varies depending on one's wealth. In other words, perceived value of luxury goods is different from different status and wealth levels, meaning that "[a] luxury good may become a normal good or even an inferior good at different income levels" (Investopedia, 2018, "Luxury Item": para. 2). Therefore, the definition of luxury goods is relative and hard to unanimously define.

There are many characteristics and factors that distinguish luxury goods from other goods, but in the end it all comes down to one common factor goods considered and declared as luxury, although available to more people than before, are not available to everybody. In order to understand the psychology behind luxury goods, and therefore their importance to the global market, it is imperative to explore all aspects of luxury goods, including perceptions, characteristics and motivations that play a major part in consumer behaviour.

Defining what actually makes goods luxury can be quite difficult, but there are some characteristics that have been defined and that label goods as luxury goods. Kasztalska (2017) argues that "[l] uxury services and goods are relative [also] because it depends on many factors and prospects" (p. 78), and the relativity of luxury goods can be divided into: "regional, temporal, economic, cultural and situational” (Kasztalska, 2017:78). For example, time relativity "is a change in the perception of goods as a luxury over time" (p. 78), because of ever changing social trends and technological progress. The process of identifying goods as luxury also goes backwards, whereas "products that were once considered to be [of] everyday [availability] are now called luxury items" (p. 78) because they are rarely available today. One example of time relativity would also be luxury Hermes Birkin bags that gain value over time and are becoming auction items. In that sense, "[l]uxury goods are not stable" (p. 78) and are susceptible to loss or gain of value over time.

According to Kasztalska (2017:80), there are several characteristics luxury goods have in common: excellent quality; high price; uniqueness; aesthetics; tradition; history; unnecessariness (Table 1). Luxury industries share some of these characteristics, but neither of those characteristics standing alone are
Pajić,M.A.

Consumer behaviour factors and contemporary trends on the luxury goods market 
Pajić, M.A.

Consumer behaviour factors and contemporary trends on the luxury goods market

Table 1 Characteristics and values of luxury goods

\begin{tabular}{|c|c|}
\hline Characteristics & Values \\
\hline Excellent quality & Financial value \\
\hline High price & Social value \\
\hline Uniqueness & Functional value \\
\hline Aesthetics & Individual value \\
\hline Tradition & \\
\hline History & \\
\hline Unnecessariness & \\
\hline
\end{tabular}

Source: Kasztalska (2017), p. 80-81.

enough to make a good a luxury one. Other specific aspects, that determine goods as luxury are specific values. Every luxury good has specific values which are also considered as characteristics of luxury goods. Kasztalska (2017:81) explores four values that are in common for every luxury good: financial value; social value; functional value; individual value (Table 1).

\subsection{Consumer behaviour motivation and characteristics}

The understanding of psychological aspects and background of consumer behaviour in buying luxury goods is key to establishing if, and in what way, online shopping affects the sales of luxury goods. According to Singh et al. (2014), consumer buying behaviour emerged as a combination of findings from other scientific fields with psychological, sociological and other related backgrounds (p. 17). Singh et al. (2014) explain that it concentrates on how consumers decide on spending money and time on purchases (p. 17). Consumer buying behaviour is a complexed process and a very important aspect of luxury goods phenomenon. In order to understand how, or even if, online shopping affects sales of luxury goods, it is important to understand how consumers perceive and react to it. To reach that understanding, it is imperative to understand consumer behaviour completely, what motivates it and in what way.

In the aspect of luxury goods, luxury-purchasing motivations have a deeper meaning for everyone included - from the consumer to the brand itself. Han et al.(2010:16) pointed out that buyers usually choose specific goods because of their desire to be associated with those who can afford them, which is also used as means of identification and self-presentation in the world. More specifically, that identification and self-presentation is sometimes used to associate or dissociate oneself with specific reference groups. Another example is, as Han et al. (2010:18) found, the fact that luxury goods manifest status through signalling. In some cases, higher prices make some consumers feel superior for being the ones of very few that can afford them. In that sense, some consumers wish to associate themselves with higher class through luxury goods, and at the same time dissociate from those they perceive inferior to themselves and as lower class for not being able to afford the same lifestyle and luxury goods. Caserta (2008) calls this phenomenon conspicuous consumption after Veblen's idea, stating that it applies to the continuous "trend of an increase in luxury good consumption because luxury goods convey wealth and thus convey status" (p. 10). Hence, those who "desire status, which is affected by perceptions of wealth, they will conspicuously consume luxury goods in order to signal their [desired] level of wealth and position themselves [as high as possible) in the social hierarchy" (Caserta, 2008:10). Those loud signals used by consumers that Han et al. (2010) call poseurs are very visible trademarks, faux and counterfeit luxury goods, and even high-priced average goods misinterpreted as luxury goods due to successful marketing strategies. This is best shown on the example of luxury handbags that are one of the most common loud signal items convenient for signalling status and conspicuous consumption. While desiring to signal wealth, but financially unable to purchase authentic luxury goods, people often tend to purchase counterfeit goods, and the most common example of that are also (luxury) handbags.

Another important aspect of consumer buying behaviour is typology. Pinki (2014) explores four types of consumer buying behaviour: "routine response"; "limited decision-making"; "extensive 
Table 2 Types and stages of consumer behaviour

\begin{tabular}{|c|c|}
\hline Problem recognising & Types \\
\hline Information searching & Routine response \\
\hline Alternatives evaluating & Limited decision-making \\
\hline Deciding about purchasing & Extensive decision-making \\
\hline Purchasing & Impulse buying \\
\hline Evaluating the experience after the purchase
\end{tabular}

Source: Pinki (2014), p. 60-61.

decision-making"; "impulse buying" (pp. 60-61) (Table 2). All of the types of consumer behaviour are facilitated by digitalisation, mostly in the form of online shopping - routine response is faster and more routine when the luxury brand is digitalised with enable online shopping, limited decision making is eased, extensive decision-making is shortened and impulsive buying is even more impulsive. In other words, digitalisation and online shopping magnify whatever phenomena they touch, which luxury brands have duly recognised and used as a catalyst for their sales growth. Furthermore, according to Pinki (2014:60), there are six stages of consumer buying process of buying luxury goods. Consumer buying behaviour is a complexed process in which the final purchase is only one of the stages of the process, and merely a small part of the process. Because of its specific complexity, not every decision-making process actually ends with purchase. According to Pinki (2014), those phases are: problem recognising; information searching; alternatives evaluating; deciding about purchasing; purchasing; evaluating the experience after the purchase (Pinki, 2014:60) (Table 2). Depending on the level of complexity, not all consumer decisions consist of all six stages. In all the stages of consumer buying process, online shopping plays a big part in bringing luxury brands closer to their consumers and vice versa, and subsequently, in improving sales of luxury goods.

According to Singh et al. (2014), main factors that are influencing consumer's buying behaviour are: "cultural factors"; "social factors"; "personal factors"; "psychological factors" (p. 18) (Table 3). While Singh et al. (2014) consider them as crucial individual factors of influence on the consumer's buying behaviour, Tekin et al. (2016:5-6) pointed out that each of those factors are actually a part of one group of characteristics affecting consum- er behaviour, defined as environmental influences or external factors. As Thangasamy and Patikar (2014:37) point out that, in order to understand how consumers make actual buying decisions, it is of crucial relevance to identify who actually makes the buying decisions, and what are the roles and influences of immediate friends, family and other members of reference groups, in order to widen the marketing tactics, strategies and influences onto the most influential members of reference groups.

Aside from aforementioned factors affecting consumer buying behaviour, Ramya and Mohamed Ali (2016:76) point out one other group of external factors - economic factors (Table 3). Economic factors encompass subfactors such as income, wealth, possessions, as well as macroeconomic conditions, that play the most important part in the decision-making process of buying luxury goods - financial ability for purchase. Besides environmental or external characteristics, Tekin et al. (2016:6-7) defined one other group of characteristics, individual differences, which affect consumer behaviour. Psychological factors or individual differences, as Tekin et al. (2016:6-7) call them, encompass factors such as motivation, perception, attitudes and beliefs (Table 3).

In order to observe and analyse certain market trends with understanding and driving relevant conclusions, consumer target groups have to be distinguished through market segmentation. The consumer background characteristics encompass various demographic, psychographic, behaviouristic and geographic traits. In this particular case and because of the nature of the luxury good that is being observed, it is difficult to undertake the market segmentation in order to distinguish the consumers of luxury handbags based on their background characteristics, merely because there are considered to be only two essential and main motives behind
Pajić, M.A.

Consumer behaviour factors and contemporary trends on the luxury goods market 
Pajić, M.A.

Consumer behaviour factors and contemporary trends on the luxury goods market

Table 3 Influences and factors that affect the consumer buying behaviour

\begin{tabular}{|c|c|}
\hline Environmental influences & Psychological influences \\
\hline Cultural factors & Motivation \\
\hline Social factors & Perception \\
\hline Personal factors & Attitude \\
\hline Psychological factors & Beliefs \\
\hline Economic factors & \\
\hline
\end{tabular}

Source: according to Tekin et al. (2016), p. 5-7; Singh et al. (2014), p. 18; Ramya and Mohamed Ali (2016), p. 76.

purchasing luxury handbags. Although there is a wide spectrum of external and internal factors that influence decision-making process and consumer buying behaviour, behind every decision and behaviour there is a combination of more than one internal factor and one external factor. Interestingly, those combinations can be different from person to person, but without those two factors that are in common to all combinations, the purchase of luxury handbag would not be made. Those factors are internal drive, as in consumer's motives, and external conditions, as in the real or stretched financial ability to purchase luxury handbags.

As McLeod (2018) points out, "Maslow's hierarchy of needs is a motivational theory in psychology comprising a five-tier model of human needs, often depicted as hierarchical levels within the pyramid" (McLeod, 2018, "Maslow's Hierarchy of Needs": para. 1). According to Maslow's hierarchy of needs, luxury handbags fulfil self-fulfilment or needs of self-actualization, such as achieving one's full potential, as well as psychological needs or esteem needs, such as prestige and feeling of accomplishment. Luxury handbags represent more than just an item fulfilling its functional purpose (Business of Fashion, 2018). They are a status symbol of economic prosperity and elegance, as well as of prestige and privilege used for showing off personal taste. Going deeper in the consumer psychology behind purchasing luxury handbags one can find emotional feelings, such as feelings of success, achievement, accomplishment and acknowledgement for hard work. Luxury handbags also represent freedom and financial, as well as emotional, independence for those who can afford luxury handbags of their choice, alongside a feeling of power, confidence and capability.

But just as there are two sides to every coin, segmentation of consumer background characteristics behind luxury handbags is not that simple. Al- though there are numerous positive and empowering feelings that luxury handbags provide, there are also some negative characteristics that lay in the background of consumer buying behaviour. Purchasing luxury handbags can often be out of misery, low self-esteem (Investopedia, 2018) and emotional instability, in hopes that owning a luxury handbag will make them happy. To lovers of luxury goods that have a tendency to measure everything through material things, luxury handbags will give a boost of self-esteem, sense of comfort and a feeling of belonging. Luxury handbags will always have consumers who will, financially comfortable or not, purchase them in the desire to reward themselves for accomplishments, show off, gain acceptance from a reference group and/or rise oneself as high as possible on the status and wealth level. For that reason, luxury handbags represent a specific and most common luxury good, and therefore an interesting case study.

Luxury goods, in conclusion, are of global influence and significance, since their core nature is presenting value, prestige and other symbols for a great number of people spread all around the world. However, scholastic literature mainly focuses on assessing the psychological aspects and influencing factors of consumer's desires for luxury goods for displays of wealth, status and prestige as consumer behaviour factors in buying luxury goods. Contemporary literature does not yet enlist digital tools as some of consumer behaviour factors in buying luxury goods, which recent relevant and expert market research reports and official statistic databases surely indicate as such.

\section{The analysis of the luxury industry trends}

A very important aspect of the consumer buying behaviour is that luxury consumers are social- 
ly engaged, both through personal and internet channels, due to globalisation and, subsequently, digitalisation. Digitalisation is a term most often misunderstood. But as Rask (2001, cited in Ivang, 2008) states, digitalisation is "the process by which industrial companies within the actor, process or product dimension is transformed from physical to digital stage" (p.13). In that sense, digitalisation encompasses digitizing a wide spectrum of business aspects, internal and external equally. Since digitalisation has taken over all industries and aspects of business, luxury brands have faced a challenge to keep their desired traditionality and exclusivity, while changing their traditional corporate and sale strategies towards digitalisation in order to follow market and industry trends. Some of the forms of digitalisation are technology, internet, online shopping and social media. They are very important for luxury brands because they are not only used for online purchases, but also for comparing prices, product features and after-sale service facilities (Deloitte, 2015).

In compliance with globalization, internet and fast track changes of every aspect of today's life, luxury industry succumbed to new trends. Although it seems that luxury industries are late bloomers when it comes to following trends, since even recently some of them refused to sell goods online, the tides have finally changed, which made them even more accessible than ever before.

According to CB Insights research brief (2018), new luxury industry trends have been found:

As corporate activity accelerates and startups targeting the luxury sector emerge, we look at 7 trends that are reshaping the luxury industry:

1. Incumbent follow startups online,

2. Renting luxury goods: a new frontier for incumbents?,

3. Upgrading the in-store experience,

4. Personalizing luxury goods online;

5. New eco-friendly luxury materials,

6. Startups make luxury goods authentication easier,

7. Blockchain makes it easier and cheaper to invest in luxury assets. (CB Insights research brief, 2018: para.1).
As it seems from CB Insights research brief (2018), six of seven trends considered to be reshaping luxury industries are some form of digitalisation. Luxury industries did not tend to sell their goods online. Almost as a rule, they were isolated in their micro locations of their stores, and only consumers who managed to physically reach them got the chance to purchase their goods. Not only did that limit their ability to acquire more market shares because of the consumers that were able to purchase the goods in their stores but were, for any reason, unable to physically reach the store, it is also believed that it might have reduced their market shares due to other substitute brands arising and doing business online. Undoubtedly, there is as an undeniable factor of brand loyalty in place, which guarantees loyalty of consumers to certain brands. Nevertheless, a brand loyalty comes from a subjective place of a consumer's perception of a brand and its image, and a brand image and consumer's perception of it is undoubtedly directly in relation with brand's attitude and actions. Thus, a brand image, and consequently consumer's brand loyalty, is susceptive to change. There is a strong belief even among the luxury industries, that has now been confirmed with the changes they have made, that if luxury industries had not started to follow global marketing trends of digitalisation and innovations, they would have faced great loss of brand equity. This indicates that digitalisation has indeed affected the sales of luxury goods.

Thankfully, this strategic shift of business digitalisation and online markets has enabled a continuous and uninterrupted growth throughout the years. More specifically, digitalisation has affected the sales of luxury goods to a vast extent, and most recent evidence of that is the $24 \%$ annual growth of global online personal luxury goods market in the period 2016-2017 (Bain and Company, 2017:17). Furthermore, Napean LLC and Unity Marketing (2018) survey helped identify seven trends from an insider's (luxury brands) point of view that the luxury brands found to be "most profoundly shaping the industry and their professional future" (p. 6). According to their research, those trends are:

1. Digital Revolution,

2. Definition of Luxury is Changing,

3. Consumer Preference, Spending Shifts,
Pajić,M.A.

Consumer behaviour factors and contemporary trends on the luxury goods market 
Pajić, M.A.

Consumer behaviour factors and contemporary trends on the luxury goods market
4. Competitive Pressures,

5. Social Turmoil,

6. Globalization,

7. Demand for innovation (Napean LLC and Unity Marketing, 2018:6).

As the most profoundly shaping trend from the luxury brands point of view is digitalisation, more specifically overall digital revolution, which indicates that digitalisation indeed affects the sales of luxury goods to a major extent. According to Napean LLC and Unity Marketing (2018), product or service innovation, which is highly connected to digitalisation, is considered to be the most influential trend impacting growth for luxury brands in 2018 (Table 4). Second most influential trend in this context are social media, followed by the rise of the digital world, finding new paths to market and globalisation, all of which indicate that digitalisation is being perceived as of vastly significant influence on the sales of luxury goods, even by the luxury brands themselves. Moreover, an inside view of how the main luxury industry segments (goods, services and suppliers) perceive the trends that influence growth, indicates that social media, alongside the rise of the digital world, are the most influential trends influencing luxury goods market.

Another interesting indicator of the influence of new developed trends is how they shifted in the period from 2017 to 2018, with social media as the highest indicated trend, followed by globalization and the rise of the digital world (Napean LLC and Unity Marketing, 2018:23). As Napean LLC and Unity Marketing (2018) point out, digital revolution resulted in new sources of information for consumers, as well as of "heritage and tradition giving way to immediacy and now" (p. 6). The definition and perception of luxury changes every day, which results in rising a very important question that potentially changes everything - what luxury actually is, how do people recognize it, and who is its arbiter (Napean LLC and Unity Marketing, 2018:6). Digitalisation is the silent catalyst in all that.

Digitalisation affects the sales of luxury goods through online shopping and other digital tools to a tremendous extent. That conclusion is evident from the $24 \%$ annual growth of global online personal luxury goods market in the period 2016-2017, as well as in information gathered by studies and surveys that have shown aspects of digitalisation, most importantly social media and digital revolution, to be the most influential trend profoundly shaping the luxury goods market and industry. More importantly, luxury brands have become aware of the significant impact the digitalisation has on the market and industry, as well as on consumer preferences, which enables them to switch their strategies from traditional ones to business digitalisation in order to improve their sales and overall growth.

Table 4 Index to trends by role played in luxury market

\begin{tabular}{|c|c|c|c|c|}
\hline & Total & Luxury goods & $\begin{array}{l}\text { Luxury services/ } \\
\text { experiences }\end{array}$ & $\begin{array}{l}\text { Suppliers to } \\
\text { Luxury companies }\end{array}$ \\
\hline Product or service innovation & 115 & 114 & 117 & 114 \\
\hline Social media & 113 & 112 & 112 & 117 \\
\hline Rise of the digital world & 113 & 110 & 111 & 119 \\
\hline Diversifying product/service offerings & 112 & 114 & 110 & 114 \\
\hline Finding new paths to market & 111 & 108 & 106 & 116 \\
\hline Globalization & 107 & 105 & 109 & 109 \\
\hline Changes in wealth distribution & 103 & 100 & 105 & 106 \\
\hline Changes in luxury consumer's media habits & 99 & 997 & 99 & 105 \\
\hline $\begin{array}{l}\text { Changes in consumer's demographics, i.e. maturing baby } \\
\text { boomers, rise of millennials }\end{array}$ & 98 & 92 & 106 & 104 \\
\hline Mergers and acquisitions & 96 & 96 & 102 & 9 \\
\hline Changes in how customers define luxury & 95 & 92 & 98 & 101 \\
\hline Changes in how luxury consumers shop & 95 & 89 & 96 & 105 \\
\hline Changes in how luxury consumers spend & 93 & 87 & 96 & 102 \\
\hline Finding and retaining well qualified employees & 92 & 92 & 94 & 93 \\
\hline Monetary policies and economic trends & 88 & 86 & 94 & 89 \\
\hline Political instability & 70 & 69 & 71 & 69 \\
\hline
\end{tabular}

Source: Napean LLC and Unity Marketing (2018), p. 21. 


\subsection{Luxury spending trends}

Luxury goods industry is a specific industry considered to be a phenomenon because of its continuous rise and growth, unlike all other industries that have had their ups and downs through time. The global luxury goods industry includes many different categories of products and services, some of which are food, drinks, fashion, handbags, cosmetics, fragrances, watches, jewellery and leisure. The Statista (2018) states that the luxury industry grows proportionally with GDP (Statista, 2018,"Value of the personal luxury": para.1), while tumbling in an unfortunate general state of economy. However, luxury goods industry has been rising for a long time. The best indicator of this is the statistic from the Statistics Portal Statista (2018) that shows the value of personal luxury goods market in the period from 1995 to 2016, with an estimation of 2017 at that time (Figure 1).

Most recent statistics are no different, showing that the trend of luxury goods industry is on a constant rise with predictions of continuous growth. According to the 16th edition of the Bain Luxury Study, Bain and Company (2017) pointed out that the luxury industry is made of nine industry segments that are led by cars, hospitality and personal goods, and "which together account for more than $80 \%$ of the total market" (p. 1). Bain and Company (2017:1) found that with all luxury segments together, "the luxury market grew by $5 \%$ [since 2016] to an estimated [EUR] 1.2 trillion globally in 2017" (p.1). Bain and Company (2017) also found interesting results of each of the luxury industry segments. For exam- ple, luxury cars sales increased by $6 \%$, reaching EUR 489 billion, luxury services such as wine and food grew $6 \%$ since 2016, and cruises grew by $14 \%$ (Bain and Company, 2017:1). Furthermore, Bain and Company (2017:1) found that global personal luxury goods market peaked reaching EUR 262 billion in 2017. Regarding luxury spending trends, according to Bain and Company (2017:1), China was a leader in luxury spending with a $15 \%$ growth at current exchange rates. In other words, the world biggest global personal luxury goods market is held by the Chinese, which is a significant insight because of the advanced digitalisation of Chinese market and purchasing tendencies. Additionally, Europe grew $6 \%$ reaching EUR 87 billion in sales, becoming the leading region in sales, while leading with the biggest global personal goods market share of $33 \%$ in 2017 (Bain and Company, 2017:10).

All the aforementioned findings show that luxury goods market is a large market of enormous value, which means it is of vast significance to all economies, as well as to the global economy in total. For that reason, following luxury industry trends and luxury spending trends is important to maintain economic prosperity and competitiveness. Therefore, the extensive effect that digitalisation has on sales of luxury goods has to be taken into consideration, for it not only affects the luxury market industry, but the global economy as well. On that note, another finding of Bain and Company (2017:19) shows that consumer still mostly use wholesales of personal luxury goods, which accounts for about two-thirds of all sales. On the other hand, retail continued its steady growth by $8 \%$ in 2017 . Bain and

Figure 1 Luxury goods market value, 1995-2017 (in billion EUR)

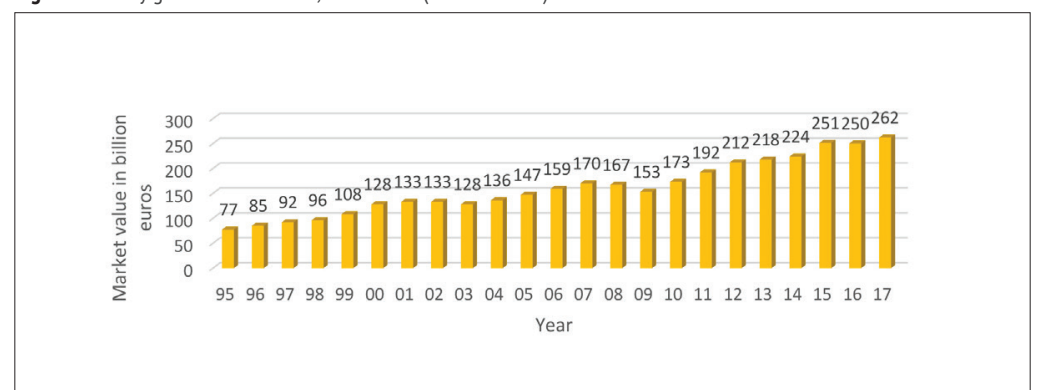

Source: Statista (2018) 
Pajić, M.A.

Consumer behaviour factors and contemporary trends on the luxury goods market
Company (2017) also showed that the growth of e-commerce continued with "online sales jumping by $24 \%$ in 2017 , reaching an overall market share of $9 \%$ " (p. 2), which is a significant growth. That finding indicates that the predicted and identified luxury industry trends, more specifically the digitalisation of business and sales, have indeed shown their presence, confirmed in the aforementioned numbers of market shares. Additionally, according to Bain and Company (2017:2), shoes, jewellery and handbags had the fastest growth in 2017. However, beauty, apparel and handbags still hold a significant share of the market, which indicates that digitalisation has largely impacted the luxury handbag market in sales and growth.

In the future of luxury, according to its findings and market trends, Bain and Company (2017:2) estimated that the market will continue to grow (4\% to $5 \%$ yearly), resulting with luxury goods market [which includes luxury handbags] value amounting EUR 295- EUR 305 billion by 2020. Moreover, Bain and Company (2017:2) expect that the luxury market's distribution through online stores will make up $25 \%$ of purchases. Furthermore, the conclusion was drawn that with such a significant rise of online shopping as a distribution channel, physical stores would somewhat need to change in order to persevere. Luxury brand's tendency toward tradition, history and heritage maintained their image through the divine and temple-like display and experience of their stores. However, the discounts of prices online, as well as on airport channels, continue to have the best results. In addition, accessories (including luxury handbags) remained to be the personal luxury goods category of the fastest and largest growth (7\% growth in 2017) (Bain and Company, 2017:20). Shoes and jewellery had the fastest growth in 2017, immediately followed by luxury handbags with the annual growth of $7 \%$ in the period 2016-2017 (Bain and Company, 2017:21). That is relevant because it indicates the importance of luxury handbags as a product category in luxury goods market, and the extent to which they have an influence on the overall luxury goods market, and subsequently, the extent to which online shopping has an effect on them.

Figure 2 Customer satisfaction analysis model

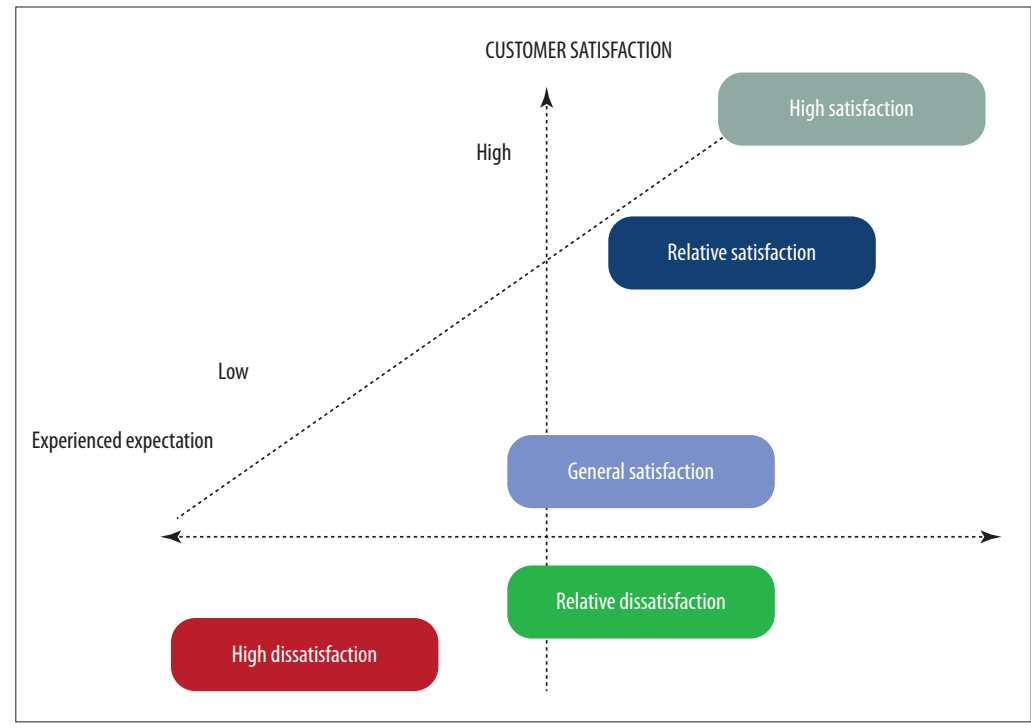

Source: Khadka and Maharjan (2017), p. 5. 
Except for sales profit, brands should aim for consumer satisfaction, for it is the only reason the consumers will stay loyal and purchase again, and consequently create sales profit. Khadka and Maharjan (2017) define consumer satisfaction as an "overall evaluation based on the total purchase and consumption experience with the good or service over time" (p. 5) (Figure 2). Because of globalization and social network, every brand's existence depends on the satisfaction of consumers and their evaluations. Consumer satisfaction is relative, for it depends solely on the consumer's perception and expectations of goods, but with the use of digitalisation, online shopping and digital communication tools, customer satisfaction can be managed more easily.

The luxury market has become truly globally managed, so managing luxury became more difficult than ever. According to new research, studies and trend, the biggest change is digitalisation, more specifically going online, and that digital impact is going to be the biggest trend of luxury industry. Also, one of the most difficult challenges as well, since digital impact threatens to diminish what luxury goods industries have built their brands on, are preserving tradition, history and heritage, as well as low level of accessibility. With social media and digital impact, this all changes. Lastly, a so far continuous growth is expected to last in all segments of luxury goods industry. Even more so if luxury brands embrace all aspects of digitalisation in their industry.

\subsection{The role of social media and digital impact}

An annual survey among 600 participants in the luxury industry by Napean LLC and Unity Marketing (2018:5) showed that players in luxury industry recognize and acknowledge the role of social media and digital impact. Regarding the Internet, Napean LLC and Unity Marketing (2018:5) found that, " $[r]$ egarding the Internet, nearly $40 \%$ of the luxury goods and service marketers currently are not selling over the Internet, though $68 \%$ of luxury goods companies are ecommerce enabled" (p. 5). They rose from $62 \%$ in 2016 to $68 \%$ in 2017.Among the brands with online sales of luxury goods, almost one third of revenues are from online sales. However,"a great number of service marketers (28\%) have no plans to sell over the Internet as compared to luxury goods marketers, only $13 \%$ of which have no plans to sell on the Internet" (Napean LLC and Unity Marketing, 2018:12).

As far as it goes to revenues coming from internet sales, $42 \%$ of luxury brands claimed to Napean LLC and Unity Marketing (2018) that revenues from online sales amount to $10 \%$ (even less) (p.12), while "[t]he average percentage of revenues coming via Internet sales is $34 \%$ overall, same as last year" (p. 12). Furthermore, Napean LLC and Unity Marketing (2018) found that "[i]n 2018 a majority (58\%) of luxury goods and experience marketers plan to spend more on advertising, with social media, Web site enhancements and Internet advertising getting the biggest boost in advertising investments" (p. 5). Napean LLC and Unity Marketing (2018) survey also showed that overall luxury goods insider's "view the Internet and social media as the magic bullet in 2018 to reach new customers, build impressions and make connections" (p. 5). Furthermore, " $[t] 0$ power innovation strategies, they turn to the news and industry trade sources to follow trends and engage in active listening and social media monitoring to hear what their customers are saying and understand what they are feeling" (Napean LLC and Unity Marketing, 2018:6). Moreover, Napean LLC and Unity Marketing (2018) survey also found " $[t]$ hree trends [that] emerged as the most positive for the growth of luxury insider's businesses. They are product and service innovation, social media and rise of the digital world, and product/service diversification" (p. 6). Finally, the trend toward digital is surely confirmed in the survey. Napean LLC and Unity Marketing (2018:15) point out that the luxury industry used digital ads of more than USD 1 billion of value in 2016, which is an increase of $63 \%$ back in 2013 , while advertising in magazines declined by $8 \%$. Using influencers for marketing has also shown significantly effective results, since luxury consumers are socially engaged. In addition to that, in terms of sales, social media and digital impact, very significant is the fact that Louis Vuitton (luxury handbag brand) is the leading luxury goods company by sales (Deloitte, 2018:26), as well as by followers on social media (Deloitte, 2018:7) and online popularity (Luxe Digital, 2018).

Internet and social media are not only used for on-
Pajić, M.A.

Consumer behaviour factors and contemporary trends on the luxury goods market 
Pajić, M.A.

Consumer behaviour factors and contemporary trends on the luxury goods market line purchases, but also for comparing prices, product features and after-sale service facilities. Therefore, digitalisation, more specifically social media, online shopping and digital impact, vastly influence sales of luxury goods. Social media is important to reach consumers, and to make them feel important and valued, and consequently satisfied. Influencers can boost the brand's social visibility, which is paramount to be conducted in the core values of the brands in order to gain the desired effect on consumers. The impact of influencers on the sales of luxury brands is vast (and enabled at all) solely because of digitalisation. Success of luxury brands depends on various factors, such as consumer satisfaction, use of online shopping, following new trends as well as understanding the role of social media, embracing it and using it properly to their advantage. Ultimately, success of luxury brands is affected by digitalisation and strategic social media involvement. Luxury brands need to balance perfectly between social media and digital tools in order to adapt to new trends in consumer behaviour changes without becoming a mass market, while retaining their exclusivity as a core aspect of luxury goods and improving sales.

\section{Consumer behaviour in buying luxury goods and the role of digitalization: the example of luxury handbags}

Although it sounds as the primary function of handbags is carrying personal things, alongside that functionality there is a specific kind of psychological and social phenomena behind luxury handbags, as opposed to other luxury goods. As the leading accessory of our time, luxury handbags today have even become auction items, purchased for investment reasons. Such example is a Hermes Birkin bag that has made the world record for being sold for USD 203,150 at the Heritage Auction in Texas (Piiroinen, 2014:36). The luxury handbag market has been significantly impacted for the better since the number of buying options for consumers is rising. Interestingly, the demand for male luxury handbags is growing as men too have started to identify luxury handbags as a lifestyle and status symbol, rather than just a functional good for women.

The best indicator of the importance of handbags is the fact that, according to Statista (2018), the revenue of handbags in Europe reached USD 8,490 million in 2018, with the expectancy of market growth of $2.8 \%$ by 2021 . Furthermore, according to Transparency Market Research Analysis (2018), the luxury handbag market revenue of Europe amounts to USD 5,215.3 million in 2018, with the expectancy of market growth of $10 \%$ by 2026 . Moreover, Europe had the biggest market share in revenue, reaching $31.8 \%$ in 2016 . Therefore, luxury handbags are a huge influencing factor on the global market. Consequently, luxury handbags market has a vast relevance to the global market and therefore, the consumer buying behaviour of luxury handbags is very important to research, understand and manage, in order to preserve the balance of the global market. According to Bain and Company (2017:2), shoes, jewellery and handbags had the fastest growth in 2017, which indicates that online shopping has largely impacted the luxury handbag market in sales and growth.

Moreover, as previously stated, shoes and jewellery had the fastest growth in 2017, immediately followed by luxury handbags with the annual growth of 7\% in the period 2016-2017 (Figure 3). That is relevant because it indicates the importance of luxury handbags as a product category in luxury goods market, and the extent to which they have an influence on the overall luxury goods market, and subsequently, the extent to which digitalisation has an effect on them.

Furthermore, Deloitte (2018:29) found that in the top 100 companies of luxury goods included in their research, only nine companies were from the bags and accessories product sector, with a luxury goods sales growth of $3.4 \%$ in 2016 and a share of $7.2 \%$ of top 100 luxury goods sales. Deloitte 2018:30) also found that, performance-wise, the sector of bags and accessories had $6.9 \%$ net profit margin in 2016 (Figure 4).

Breaking habits is always hard, but the studies have shown that changes need to be made in order to match the changes happening in the market globally, and therefore persevere. Technological progress, globalization and internet have started tides in all segments in the global markets that have only become bigger in time. Accordingly, there has also been a change in consumers' perception. 
Figure 3 Annual growth of global personal luxury goods market, by product category, 2017

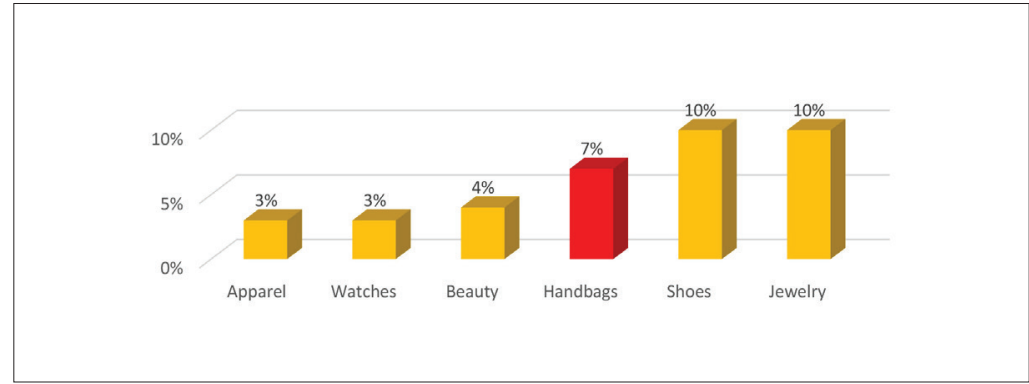

Source: Bain \& Company (2017), p. 21.

Figure 4 Performance by product sector

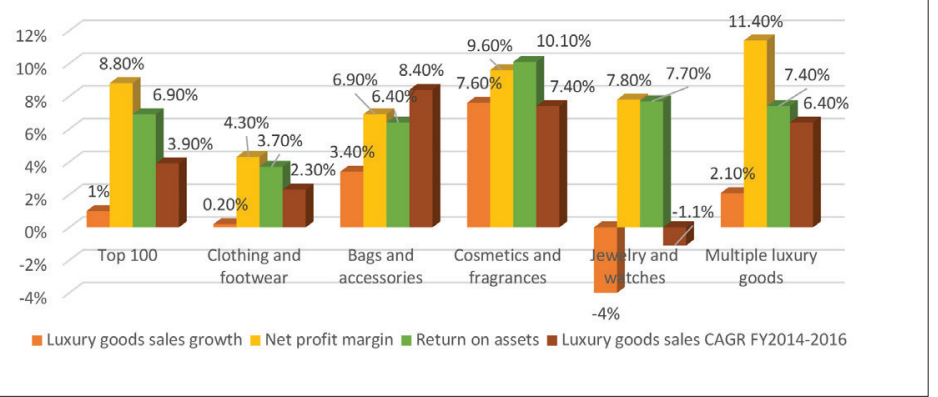

Source: Deloitte (2018), p. 30.

So-called millennials make new changes and tides themselves, which calls for readjusting business and marketing strategies to best suit their needs. For that reason, old concepts of stores as temples that are not meant for everyone and thus have to be slightly changed, better said altered, into what today's market and consumers need. Next generations have different values, although the concept of luxury will probably never change. The only thing that will stay relative about it, as it already has so far, is the object considered as luxury good at a particular moment in time. With that being said, the obvious conclusion is that brands that actively respond to the ongoing shift in the new generation of consumers and subsequently their demands for digital tools such as online shopping, as well as needs for and perception of luxury, will tend to grow significantly. In addition to that is the fact that accessories, including luxury handbags, remained to be the personal luxury goods category of the fastest and largest growth (9\% growth in 2017) (Bain and Company, 2017:20).

Luxury handbags are a huge influencing factor on the global market. Consequently, luxury handbags market has a vast relevance to the global market and therefore, the consumer buying behaviour of luxury handbags is very important to research, understand and manage, in order to preserve the balance of the global market.

\section{Conclusion}

Consumer buying behaviour is a complex process and a very important aspect of luxury goods phe-
Pajić,M.A.

Consumer behaviour factors and contemporary trends on the luxury goods market 
Pajić, M.A.

Consumer behaviour factors and contemporary trends on the luxury goods market nomenon, so the results gained on this subject have been enlightening and important for conducting further research studies, considering the unparalleled growth of luxury market and industry. Luxury handbags represent a good example (case study) for the research, since the recent examples and data on digital sales of these products are available. Since these trends are rather new,especially in this category of products, the research contributes to the existing literature by bringing the contemporary development of demand for luxury products and services and examines it in the light of economic theory, and contributing to the literature on the digitalisation and online shopping as some of the consumer behaviour factors in buying luxury goods. The result of this research is identifying the role of digitalisation and future trends in the consumer behaviour when buying luxury goods, as well as luxury industry and brand strategies as an answer to all digitalisation challenges. These results will help in understanding the changing concepts in the consumer behaviour imposed by digitalisation in the sector of luxury goods, especially having in mind that $10 \%$ or less of luxury purchases relates to digital sales (Napean LLC and Unity Marketing, 2018:12), with an estimation "that online sales for personal luxury goods will make up $25 \%$ of the market by 2025 " (Bain and Company, 2017:23). It was found that there are six stages of consumer buying process and four types of consumer buying behaviour (Pinki, 2014), as well as four major factors that influence consumer's buying behaviour (Singh et al., 2014), and specific individual differences (Tekin et al., 2016) that highly affect consumer behaviour. None of the aforementioned aspects of luxury consumer buying behaviour have been said to encompass digital tools such as online shopping. The luxury goods industry has been on a rise for a long time and has been changing macroeconomic climates. The best indicator of this is the statistic showing the growth of the luxury market of $5 \%$ since 2016 (EUR 1.2 trillion globally in 2017), as well as that the market of luxury goods reached a record high EUR 262 billion (Bain and Company, 2017:6), which makes this phenomenon of consumer behaviour in buying luxury goods, more specifically luxury handbags, and the impact of digitalization and online shopping, of great influence and potential, as well as of academic and practical relevance. Also, the predictions are that the market will further grow (4\%-5\%), predicting that the market for personal goods will reach EUR 295 - EUR 305 billion by 2020 . Moreover, the statistical data indicates the importance of handbags. The luxury handbag market revenue of Europe amounts to USD 5,215.3 million in 2018, with the expectancy of market growth of $10 \%$ by 2026 (Transparency Market Research Analysis, 2018). Furthermore, due to digitalisation, online sales for personal luxury goods (including luxury handbags) will hold $25 \%$ of the market by 2025 , growing $4 \%$ - $5 \%$ per year (Bain and Company, 2017:24), which evidently shows that online shopping has affected the sales of all luxury goods, including luxury handbags, to a significant extent. Technological progress, globalization and internet have started and even forced changes in all segments in the global markets. Subsequently, there has also been a change in consumers' perception which calls for readjusting business and marketing strategies to best suit consumer needs in order to improve sales. In compliance with globalization, internet and fast-track changes of every aspect of today's life, luxury industry succumbed to new trends. Digitalisation was found to be a huge trend in luxury goods industry that is expected to last indefinitely (CB Insights research brief, 2018; Napean LLC and Unity Marketing, 2018:6). More specifically, there are new trends in place that are reshaping luxury industries, many of which are some form of digitalisation (CB Insights research brief, 2018; Napean LLC and Unity Marketing, 2018:6). Accordingly, luxury brands that actively respond to the new trends and ongoing shift in the generation of consumers and subsequently their demands for digitalisation, as well as needs for and perception of luxury, will tend to grow significantly. In fact, revenues coming from the internet sales show that $42 \%$ of luxury brands claimed that revenues from online sales amount to $10 \%$ (even less) (Napean LLC and Unity Marketing, 2018:12), while "[t]he average percentage of revenues coming via Internet sales is 34\% overall" (Napean LLC and Unity Marketing, 2018:12). The average percentage of revenues coming Via Internet sales is 34\% overall. Furthermore, in 2018 a majority (58\%) of luxury good brands planned to use more social media, web site and other online advertising (Napean LLC and Unity Marketing, 2018:5). Additionally, the growth 
of online sales continued rising by $24 \%$ in 2017 , acquiring a market share of $9 \%$, which indicates that the identified luxury industry trends have indeed shown their influence through aforementioned numbers of market shares (Bain and Company, 2017:2). In terms of sales, social media and digital impact, the comparative analysis has shown that Louis Vuitton (luxury handbag brand) is the leading luxury goods company by sales (Deloitte, 2018:26), as well as by followers on social media (Deloitte, 2018:7) and online popularity (Luxe Digital, 2018). These coinciding results indicate that there is a connection between Louis Vuitton being the leading luxury brand by sales, as well as the leading luxury brand by popularity online and by followers on social media, which ultimately indicates that digitalisation and its various tools have a crucial effect on sales of all luxury goods, luxury handbags included. In order to grow and nurture a brand's image and sales, it is of imperative and crucial importance to include online shopping, social media and other digital tools into luxury brand's marketing, sales and overall business strategies. Limitations of this research were lack of available specific data, such as market reports of specific segments and goods, more specifically of luxury handbags, that would be in compliance with the research and therefore very well incorporated for the purposes of backing up certain aspects of the paper. Another limitation was the scarceness of prior comprehensive research studies on this particular topic, requiring to limit the scope of analysis and drawing conclusions based on the available data that was managed to be acquired. Recommendation for further research is a constructive future research that can address the same research problem in a different setting, and in a new context, location and/or culture. For example, the research could also shift focus from luxury handbags to luxury cars in a specific region, and be re-assessed in two-years' time, in order to expand the theory and framework addressed in this research to confirm the current results and findings, or to achieve new ones.
Pajić, M.A.

Consumer behaviour factors and contemporary trends on the luxury goods market

\section{References}

Amaral, N. B., Loken, B. (2016) Viewing usage of counterfeit luxury goods: Social identity and social hierarchy effects on dilution and enhancement of genuine luxury brands. Journal of Consumer Psychology, 26 (4): 483-495.

Ayupp, K., Ling, L. N. \& Tudin,A.R.(2013) An Analysis of Luxury Product Purchasing Behaviour of Malaysian University Students. Asian Journal of Social Sciences \& Humanities, 2(4): 219-227.

Bain \& Company (2017) Luxury Goods Worldwide Market Study, Fall - Winter 2017.Available at: https:// www.bain.com.kw/contentassets/913fa48282034511b178b0f4b7cc3d9a/bain_report_global_luxury_report_2017.pdf [12.11.2018].

Caserta, K. (2008) Luxury Good Demand. BA, Boston College. Available at: https://dlib.bc.edu/islandora/ object/bc-ir:102116/datastream/PDF/view [13.11.2018].

CB Insight (2018) The Future of Luxury: 7 Trends Reshaping the Luxury Industry. Available at: https:// www.cbinsights.com/research/future-luxury-trends/ [12.11.2018].

Deloitte (2018) Global Powers of Luxury Goods 2018. Shaping the Future of the Luxury Industry. Available at: https://www2.deloitte.com/content/dam/Deloitte/at/Documents/consumer-business/deloitte-global-powers-of-luxury-goods-2018.pdf [13.11.2018].

Deloitte (2015) The Luxury Opportunity. The evolving UK luxury consumer - and how luxury brands can respond. Available at: https://www2.deloitte.com/content/dam/Deloitte/uk/Documents/consumer-business/deloitte-uk-consumer-the-luxury-opportunity.pdf [13.11.2018]. 
Pajić, M.A.

Consumer behaviour factors and contemporary trends on the luxury goods market
Fuerst, F., Shimizu, C. (2016) Green luxury goods? The economics of eco-labels in the Japanese housing market. Journal of the Japanese and International Economies, 39: 108-122.

Gordon, L., Roberts, F. (2017) The Big Picture: Global Luxury Goods. Euromonitor International. Available at: https://blog.euromonitor.com/big-picture-global-luxury-goods/ [14.11.2018].

Han, J., Nunes, J. C. \& Dreze, X. (2010) Signaling Status with Luxury Goods: The Role of Brand Prominence. Journal of Marketing, 74(4): 15-30.

Hennigs N., Klarmann C., Behrens S., Wiedmann KP.(2016) Consumer Desire for Luxury Brands: Individual Luxury Value Perception and Luxury Consumption. In: Campbell C., Ma J. (eds) Looking Forward, Looking Back: Drawing on the Past to Shape the Future of Marketing. Developments in Marketing Science: Proceedings of the Academy of Marketing Science. Springer, Cham; pp. 294-294. Available at: https://link.springer.com/ chapter/10.1007/978-3-319-24184-5_78 [14.11.2018].

Hennigs, N., Wiedmann, K. P., Klarmann, C., Behrens, S., Jung, J., \& Hwang, C. S. (2015) When the original is beyond reach: consumer perception and demand for counterfeit luxury goods in Germany and South Korea. Luxury Research Journal, 1(1): 58-75.

Investopedia (2018) The Psychology Behind Why People Buy Luxury Goods. Available at: https://www. investopedia.com/articles/personal-finance/091115/psychology-behind-why-people-buy-luxury-goods. asp [31.12.2018].

Ivang, R. (2008) The language of digitalisation - An extract from the Ph.D. dissertation "Towards a new understanding of the digital strategic process". Center for International Virksomhedsøkonomi, Department of business studies,_Aalborg University.Available at: http://www.ivang.dk/download/pick_my_brain/the_language_of_digitalisation.pdf [30.12.2018].

Kasztalska,A. M.(2017) The Economic Theory of Luxury Goods. International Marketing and Management of Innovations. International Scientific E-Journal, No.2. Available at: http://immi.ath.bielsko.pl/2017/02/06/ the-economic-theory-of-luxury-goods/ [11.11.2018].

Khadka, K., Maharjan, S. (2017) Customer Satisfaction and Customer Loyalty. Centria University of Applied Sciences Pietarsaari. Available at: https://www.theseus.fi/bitstream/handle/10024/139650/khadka_kabu\%20\%20and\%20\%20maharjan_\%20soniya.pdf?sequence=1 [13.11.2018].

Luxe Digital (2018) The 15 Most Popular Luxury Brands Online In 2018.Available at: https://luxe.digital/ digital-luxury-ranking/most-popular-luxury-brands/ [13.11.2018].

McLeod, S. (2018) Maslow's Hierarchy of Needs. Simply Psychology. Available at: https://www.simplypsychology.org/maslow.html [13.11.2018].

Napean LLC and Unity Marketing (2018) State of Luxury 2018 The Insider View. Available at: https:// www.luxurydaily.com/wp-content/uploads/2017/12/StateofLuxury2018.pdf [13.11.2018].

Nwankwo, S., Hamelin, N., Khaled, M. (2014) Consumer values, motivation and purchase intention for luxury goods. Journal of retailing and consumer services, 21(5): 735-744.

Pinki, R. (2014) Factors Influencing Consumer Behaviour. International Journal of Current Research and Academic Review, 2(9): 52-61.

Piiroinen, R. (2014) Luxury Handbags as an Alternative Investment? International Business Administration. Available at: https://core.ac.uk/download/pdf/38115668.pdf [13.11.2018].

Ramya, N., Mohamed Ali, S.A. (2016) Factors Affecting Consumer Buying Behaviour. International Journal of Applied Research, 2(10): 76-80.

Sahney, A. (2016) A Review of Brand Image and Its Impact on Buying Behaviour. International Journal of Academic Research and Development,1(8): 1-3.

Sharma, M. K.(2014) The Impact on Consumer Buying Behaviour: Cognitive Dissonance. Global Journal of 
Sherafatpour, M., Niksiar, B. (2015) Factors Influencing Interest to the Purchase of Luxury Brands Among Consumers (Case Study: Isfahan Province). International Conference on Business, Marketing \& Information System Management, (BMISM'15) Nov. 25-26, 2015 Paris (France).

Shulman, A. (2017) The Psychology of Designer Handbags. Business of Fashion. Available at: https://www. businessoffashion.com/articles/opinion/the-psychology-of-the-designer-handbag [31.12.2018].

Singh, A., Dhayal, N., Shamim, A. (2014) Consumer Buying Behaviour. International Research Journal of Management Sociology \& Humanity, 5(12): 17-21.

Statista (2017) Global Luxury Goods Industry - Statistics \& Facts.Available at: https://www.statista.com/ topics/1110/global-luxury-goods-industry/ [13.11.2018].

Statista (2018) Handbags Europe. Available at: https:/www.statista.com/outlook/13020200/102/handbags/europe [13.11.2018].

Statista (2017) Luxury Brand Social Media Engagement Generated By Top Influencers 2017 Available at: https://www.statista.com/statistics/246866/luxury-brand-social-media-buzz-top-influencers/[13.11.2018].

Statista (2018) Value of the personal luxury goods market worldwide from 1995 to 2017 Available at: https://www.statista.com/statistics/266503/value-of-the-personal-luxury-goods-market-worldwide/ [13.11.2018].

Thangasamy, E., Patikar, G. (2014) Factors Influencing Consumer Buying Behaviour: A Case Study. Global Journal of management and Business Research: E Marketing, 14(5): 36-42.

Tekin, G., Yiltay, S., Ayaz., E. (2016) The Effect of Brand Image on Consumer Behaviour: Case Study of Louis Vuitton-Moet Hennessy. International Journal of Academic Value Studies, 2(1): 1-24.

Transparency Market Research Analysis (2018) Luxury Handbag market - Snapshot. Available at: https:// www.transparencymarketresearch.com/luxury-handbag-market.html [13.11.2018].

Yang, W., Mattila,A. S. (2017) The impact of status seeking on consumers' word of mouth and product preference - A comparison between luxury hospitality services and luxury goods. Journal of Hospitality \& Tourism Research, 41(1): 3-22.

\section{Pajić, M.A.}

Consumer behaviour factors and contemporary trends on the luxury goods market 
